\title{
Cytological Studies in Cyperaceae with Special Reference to its Taxonomy I
}

\author{
S.P. Rath and S.N. Patnaik \\ Cytogenetics Laboratory, P. G. Department of Botany, \\ Utkal University, Bhubaneswar, India
}

Received November 25, 1972

\section{Introduction}

Cyperaceae is a large family comprising of about 80 genera and 3000 species in the world flora. The dominant genera of the family are Cyperus L. (ca. 700 spp.), Scirpus L. (ca. 200 spp.) Rhynchospora Vahl (ca. 200 spp.) Eleocharis R. Br. (ca. 150 spp.), Fimbristylis Vahl (ca. 125 spp.) and Scleria Berg. (ca. 100 spp.).

Except the study of the general flora by Hooker (1894), Cooke (1901, 1908), Gamble and Fischer $(1915,1936)$, Duthie $(1903,1929)$ Prain (1903) Haines (1921, 1924), very few workers worked on Indian Cyperaceae in particular. Recently Sabnis (1962), Stewart (1967), Korlahalli (1967), Vartak (1966) and others have worked on the taxonomy of the family from different regions of the country. However, studies of Clarke (1909) are considered to be classic works in this family.

Study of cytology and reports on the chromosome numbers are very meager in view of the large number of species within this family. Few reports on the chromosome numbers of different members of the family were made by Piech (1928) Hicks (1929), Heilborn (1939) and Tanaka (1939 a, b, 1940). Recently few workers like Sharma and Bal (1956), Sharma (1962) and Werner (1967) worked on the cytology of very few species of the family. A recent report on the cytology of Indian Cyperaceae has been reported to be published by Sanyal and Sharma in Cytologia which has not been available to the authors.

Padhye et al. (1960, 67, 70 and 71) have studied the embryology of some members of the family. In view of large number of species under various genera, the family has posed serious problems in it's taxonomy. In certain cases lines of demarcation are not very much distinct between different genera as a result of which frequent transfers of different members are being made from one genus to the other. More strikingly the genera like Kyllinga Rottb. Juncellus Kunth and Pycreus Beauv. have now been merged under Cyperus $\mathrm{L}$.

Keeping these in view a cytotaxonomic investigation in the family Cyperaceae was under taken. It was proposed to study the cytology, specially the chromosome numbers and to utilise these cytological findings in solving some of the taxonomic tangles which would arise from the survey and identification of various members of the family from this region. 
Materials and methods

Cytological investigation was mostly done through meiotic analysis. For the purpose very young spikelets often inside the sheaths were collected and fixed. The anthers at the proper stage of meiosis are so small that a stereomicroscope is very much needed for dissecting them out. The usual squashing procedure for anthers was followed and of the various types of the stains (acetocarmine, aceto-orcein, propino-carmine), aceto-carmine $(2 \%)$ proved to be most suitable. Feulgen stain could not be successfully used due to the very small size of the anthers.

While squashing the anthers, a great difficulty was experienced due to the immediate staining of the cytoplasm. To obviate this difficulty aceto-carmine of lower concentration was used but was not of much avail. Various types of fixatives such as acetic-alcohol $(1: 3,1: 2,1: 1)$ chloroform-acetic-alcohol $(1: 1: 1,3: 1: 4)$ were tried but no success was achieved. Due to this reason cells at proper stage were immediately being photographed and hardly these could be maintained in permanent slides. Very few slides in which cells did not develop much cytoplasmic staining were made permanent following the method of separating slides and cover slips, in tertiary-butyl alcohol and remounting the cover slip in euparol.

\section{Observations}

During the present investigation, members of Cyperaceae were collected mostly in and around Bhubaneswar, the Capital city of the state of Orissa. During one season, 53 species belonging to 7 genera could be collected. Amongst the present collection large number of species were found to belong to 2 dominant genera viz. Cyperus L. (24 spp.) and Fimbristylis Vahl (21 spp.).

During this investigation, 24 species belonging to 5 genera namely Fimbristylis vahl, Cyperus L. (including Pycreus Beauv. and Juncellus Kunth) Scirpus L., Lipocarpha Br. and Eleocharis $\mathrm{R}$. Br. could be worked out. Of these, chromosome numbers are recorded here for the first time in 15 species $(*)$ and different numbers are recorded against previous reports for $6 \operatorname{species}\left({ }^{* *}\right)$.

Though there is difficulty for studying the meiosis in the members of Cyperaceae as indicated previously, there is a little advantage for the study of haploid chromosomes in the anthers because out of the 4 microspore nuclei produced after meiosis, only one develops further, while the other 3 become pushed towards one end of the mother cell. Functional nucleus soon enters into a mitotic division. Thus the haploid numbers can be determined either at diakinesis of the pollen mother cell or at pollen mitosis occuring inside the same cell.

Photographs of both kinds of cells have been taken in different members for depicting the haploid chromosome numbers, some of which have been illustrated in Figs. 1-20.

The list of species cytologically studied with haploid chromosome numbers along with previous reports are presented in Table 1.

All the 14 species of Fimbristylis Vahl cytologically investigated conformed to a single basic chromosome number of $\mathrm{x}=5$. Two species viz. $F$. argentea Vahl 
and $F$. dichotoma (L.) Vahl were proved to be tetraploids possessing the haploid chromosome number of $\mathrm{n}=10$ in each of them, where as the rest of the 12 species were found to be diploids and were uniformly characterised by $n=5$.

Amongst the 2 tetraploid species $F$. argentea Vahl was found to possess comparatively smaller pollen mother cells and pollens than that of $F$. dichotoma

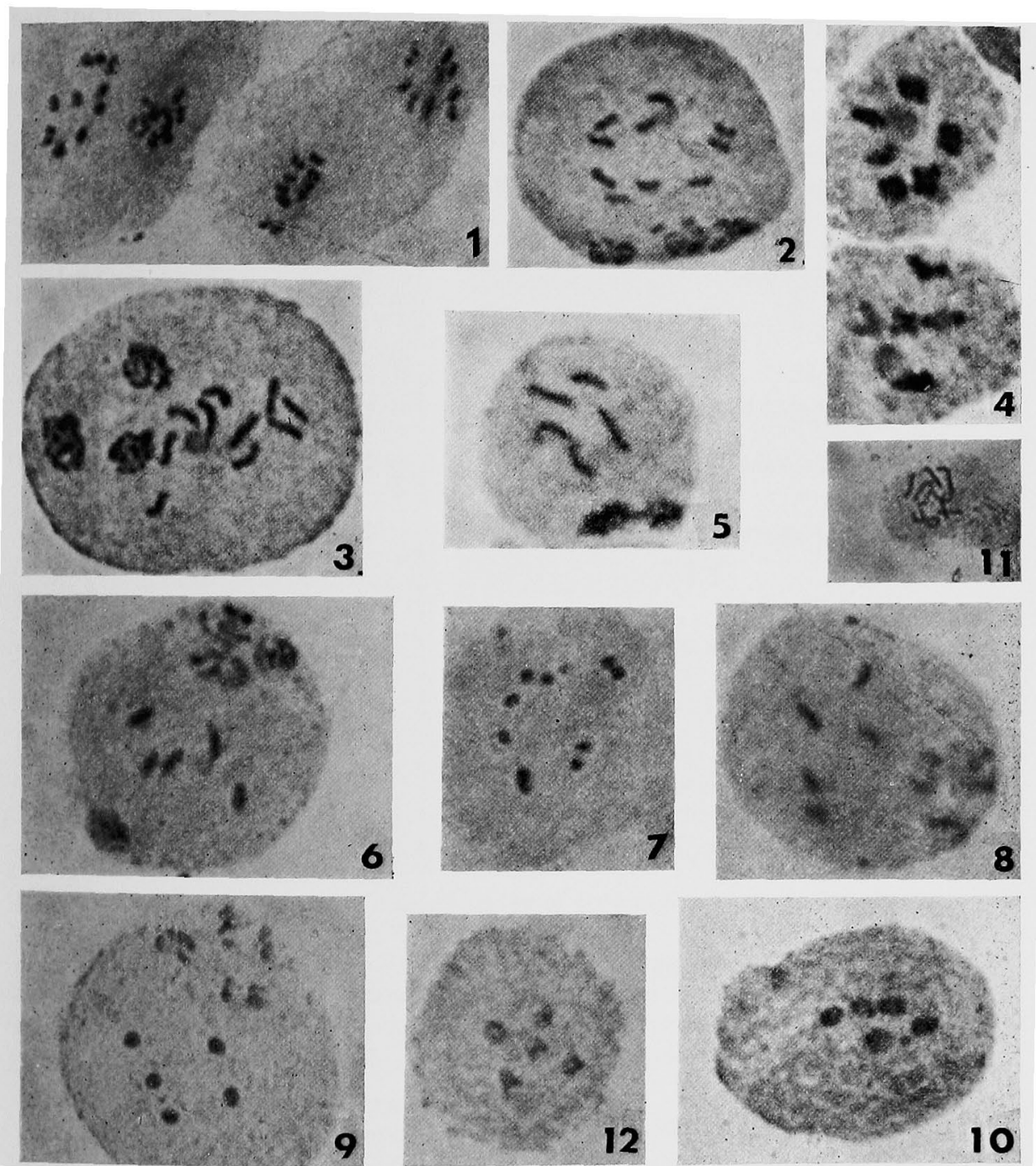

Figs. 1-12. Photomicrographs of different species of Fimbristylis Vahl. All figures are reproduced at a magnification of $\times 1200$. $1, F$. argentea $\mathrm{Vahl} \mathrm{n}=10$, anaphase. $2, F$. argentea $\mathrm{Vahl} \mathrm{n}=10$, pollen mitosis. $3, F$. dichotoma (L.) Vahl $\mathrm{n}=10$, pollen mitosis. $4, F$. acuminata Vahl $\mathrm{n}=5$, diakinesis. 5, F. complanata (Retz.) Link $\mathrm{n}=5$, pollen mitotic metaphase. $6, F$. quinquangularis (Vahl) Kunth $\mathrm{n}=5$, pollen mitotic metaphase. 7, F. sub-bispicata Nees $\mathrm{n}=5$, early anaphase. 8, F. schoenoides Vahl, metaphase of pollen mitosis. 9, F. diphylla (Retz.) Vahl, $\mathrm{n}=5$, pollen mitotic metaphase. 10,F. aestivalis (Retz.) Vahl $\mathrm{n}=5$, metaphase $\mathrm{I}$. 11, $F$. setacea Benth. $\mathrm{n}=5$, late metaphase. 12, F. spathacea Roth. $\mathrm{n}=5$, diakinesis. 
(L.) Vahl, whose cells were found to be comparatively larger than all other species of the genus cytologically studied.

The genus Cyperus $L$. is here treated in the wider sense embracing the species of Pycreus Beauv. and Juncellus Kunth. Five species of the genus could be cytologically studied. As contrast to a single basic chromosome number in Fimbristylis

Table 1

\begin{tabular}{|c|c|c|c|}
\hline Name of the species & $\begin{array}{l}\text { Haploid } \\
\text { chromosome } \\
\text { number }\end{array}$ & $\begin{array}{l}\text { Previous } \\
\text { report }\end{array}$ & Authors \\
\hline${ }^{* *}$ Fimbristylis dichotoma $(\mathrm{L}$.$) Vahl$ & $\mathrm{n}=10$ & $\begin{array}{c}2 n=10 \\
n=5\end{array}$ & $\begin{array}{l}\text { Sharma and Bal } \\
\text { Sharma }\end{array}$ \\
\hline${ }^{*} F$. argentea Vahl & $\mathrm{n}=10$ & - & - \\
\hline${ }^{* *} F$. aestivalis (Retz.) Vahl & $\mathrm{n}=5$ & $\begin{array}{l}2 n=10 \\
2 n=20\end{array}$ & $\begin{array}{l}\text { Sharma and Bal } \\
\text { Tanaka }\end{array}$ \\
\hline${ }^{*} F$. setacea Benth. & $\mathrm{n}=5$ & - & 一 \\
\hline${ }^{*} F$, acuminata Vahl & $\mathrm{n}=5$ & - & - \\
\hline${ }^{* *} F$. complanata (Retz.) Link & $\mathrm{n}=\mathbf{5}$ & $\begin{aligned} n & =5 \\
2 n & =16\end{aligned}$ & $\begin{array}{l}\text { Sharma } \\
\text { Tanaka }\end{array}$ \\
\hline${ }^{* *} F$. diphylla (Retz.) Vahl & $\mathrm{n}=5$ & $2 \mathrm{n}=20$ & Sharma and Bal \\
\hline${ }^{*} F$. spathacea Roth. & $\mathrm{n}=5$ & - & - \\
\hline${ }^{* *} F$. ovata (Burm.f.) Kern & $\mathrm{n}=5$ & $2 n=20$ & $\begin{array}{l}\text { Sharma and Bal } \\
\text { as } F . \text { monostachya } \\
\text { Hassk. }\end{array}$ \\
\hline${ }^{*} F$. tetragona $\mathrm{R} . \mathrm{Br}$. & $\mathrm{n}=5$ & 一 & - \\
\hline${ }^{*} F$. quinquangularis (Vahl) Kunth & $\mathrm{n}=5$ & - & - \\
\hline${ }^{*} F$. sub-bispicata Nees & $\mathrm{n}=5$ & - & - \\
\hline${ }^{*} F$. schoenoides (Retz.) Vahl & $\mathrm{n}=5$ & 一 & - \\
\hline F. miliacea (L.) Vahl & $\mathrm{n}=5$ & $2 n=10$ & Tanaka \\
\hline $\begin{array}{l}{ }^{*} \text { Cyperus substramineus Kukenth. } \\
(=\text { Pycreus stramineus Beauv. })\end{array}$ & $\mathrm{n}=21$ & 一 & - \\
\hline $\begin{array}{l}{ }^{*} \text { Cyperus inundatus } \mathrm{Roxb} . \\
(=\text { Juncellus inundatus } \mathrm{Cl} .)\end{array}$ & $\mathrm{n}=\mathbf{2 9}$ & - & - \\
\hline${ }^{*}$ C. tenuispica Steud. & $\mathrm{n}=8$ & - & - \\
\hline${ }^{*}$ C. pilosus Vahl & $\mathrm{n}=18$ & - & 一 \\
\hline${ }^{*} C$, pulcherrimus Willd. ex Kunth. & $\mathrm{n}=13$ & 一 & - \\
\hline Scirpus supinus L. & $\mathrm{n}=14$ & $2 n=28$ & Sharma and Bal \\
\hline${ }^{* *}$ S. articulatus $\mathrm{L}$. & $\mathrm{n}=15$ & $2 n=32$ & Sharma and Bal \\
\hline $\begin{array}{l}{ }^{*} \text { Lipocarpha chinensis } \\
\text { (Osbeck.) Kern }\end{array}$ & $n=13$ & - & 一 \\
\hline $\begin{array}{l}\text { *Eleocharis chaetaria } \\
\text { Roem. et Sch. }\end{array}$ & $\mathrm{n}=5$ & - & - \\
\hline $\begin{array}{l}\text { Eleocharis dulcis (Burm.f.) } \\
\text { Trin ex Henschel. }\end{array}$ & Above 100 & $\mathrm{n}=\mathrm{c} .108$ & Patnaik and Guru \\
\hline
\end{tabular}

Vahl, there is a wide array of haploid numbers in this genus. Cyperus substramineus Kukenth. characterised by $n=21$, showed marked variation in the size of the bivalents. Cyperus inundatus Roxb. was found to possess 29 bivalents which are comparatively smaller in size than those of the previous species and are found to 
take less stain, as a result of which often it becomes difficult to differentiate them from the cytoplasm. Cyperus tenuispica Steud. was found to be characterized by $\mathrm{n}=8$ conforming to one of the basic numbers already reported for the genus but this report of $\mathrm{n}=8$ is the lowest haploid number yet recorded for the genus Cyperus L. Cyperus pilosus Vahl characterised by $\mathrm{n}=18$ conformed to the other basic number of $\mathrm{x}=9$ already established for the genus. Cyperus pulcherrimus Willd. also studied here for the first time revealed $n=13$. This is a record of a new basic chromosome number for the genus.
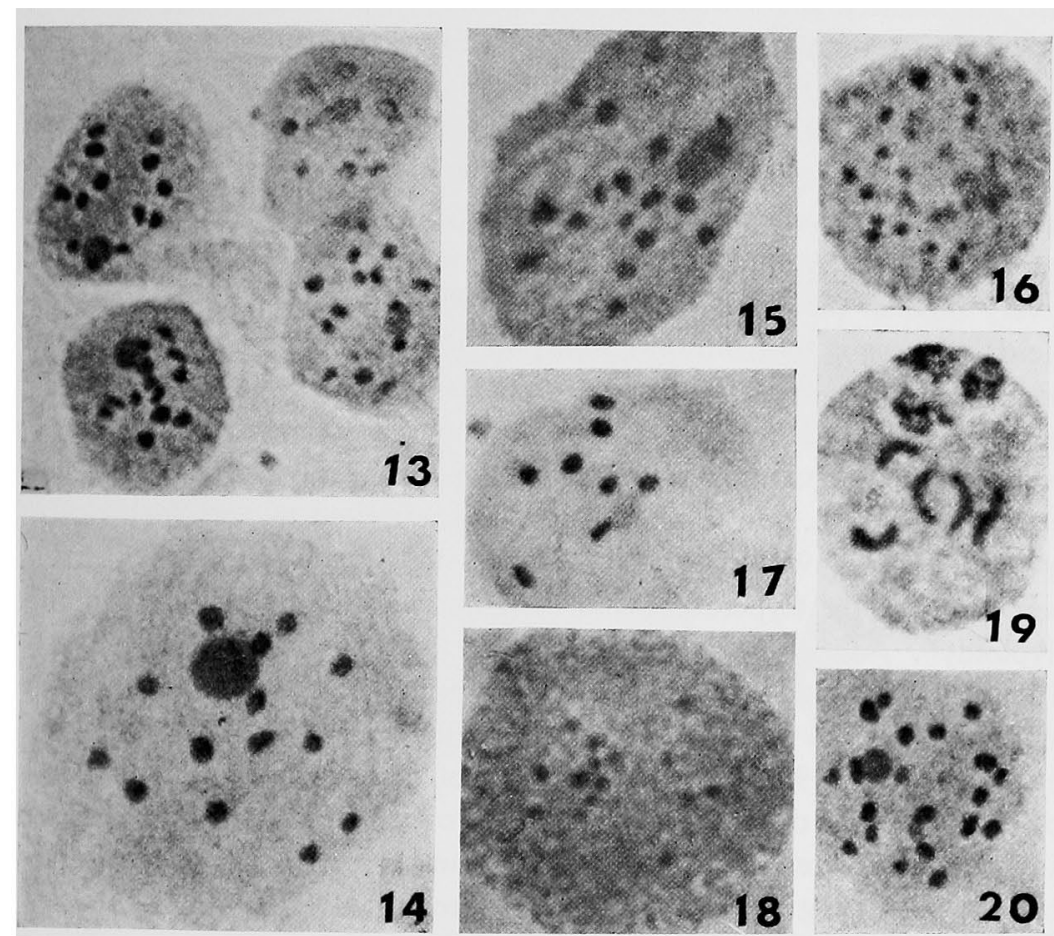

Figs. 13-20. Photomicrographs of different species of Cyperus L., Scirpus L. and Eleocharis R.Br. All figures are reproduced at a magnification of $\times 1,200$. 13, Cyperus pulcherrimus Willd, $n=13$, diakinesis. 14, Scirpus supinus $\mathrm{L} . \mathrm{n}=14$, diakinesis. 15, Cyperus pilosus Vahl, $\mathrm{n}=18$, diakinesis. 16, Cyperus inundatus Roxb. $\mathrm{n}=29$, diakinesis. 17, Cyperus tenuispica Steud. $\mathrm{n}=8$, diakinesis. 18, Scirpus articulatus L. $\mathrm{n}=15$, diakinesis. 19, Eleocharis Chaetaria Roem. et. Sch. $\mathrm{n}=5$, pollen mitotic metaphase I. 20, Cyperus substramineus Kukenth. $\mathrm{n}=21$ diakinesis.

Cytological analysis of 2 species of Scirpus $L$. could be done during the present study. Scirpus supinus L. was found to possess $n=14$ which confirmed the earlier report of Sharma and Bal (1956) for this species, but $S$. articulatus L. studied here revealed $n=15$ against the previous finding of $2 n=32$ by Sharma and Bal (1956). The two species however show marked difference in the size of the bivalents, size and persistence of nucleoli and stainability of the chromosomes.

One species of the genus Lipocarpha $\mathrm{Br}$. viz. Lipocarpha chinensis (Osbeck.) Kern could be studied revealing the haploid chromosome number of $n=13$. 
Eleocharis dulcis (Burm f.) Trin ex Henschel. posed a great amount of difficulty in counting the chromosome numbers as there were very large number of small sized bivalents.

\section{Discussion}

In view of the large number of genera and species included under Cyperaceae it is quite likely that taxonomically the family would pose many problems. This has also necessitated the division of the family into number of sections, tribes and subtribes. Lines of demarcation between genera are sometimes very ill defined which is evident from the recent merger of the genera like Juncellus Kunth, Pycreus Beauv., and Kyllinga Rottb. with Cyperus L.

In reviewing the cytological data it is found that while the family Gramineae has been very extensively worked out, cytology of very few members in the family Cyperaceae have been studied. The percentage of polyploidy has been reported to be very high in the family as Stebbins (1950) remarks that "the percentage of polyploids varies greatly from one family to another being particularly high in the Gramineae, the Cyperaceae and the Rosaceae". The overall cytological picture in the family reveals that both euploidy and aneuploidy have played major role in the evolution of the various members within the family. The genera like Eleocharis $\mathrm{R}$. Br., Carex L. and Cyperus L. are characterised by very high rate of aneuploidy and Stebbins (1950) suggested that "the high aneuploid series of chromosome numbers found in the Cyperaceae and the Juncaceae are probably a modified form of polyploidy".

Tanaka (1939) studying 10 species of Fimbristylis Vahl discovered four basic chromosome numbers viz. $x=5,6,8,11$. But Sharma and Bal (1956) studying 4 species and Sharma (1962) studying 2 species of the genus found that all the Indian species conformed to only one basic number of $x=5$. Of these, five species were diploids, each characterised by the haploid number of $n=5$ and one proved to be a tetraploid possessing $n=10$. During the present investigation 14 species of the genus were studied of which two were tetraploids having $n=10$ and the rest were diploids each showing $n=5$ at meiosis or at subsequent pollen mitosis. So even though the frequency of polyploidy is very low, it is evident that euploidy has played definite role in the speciation within this genus. No aneuploidy has yet been recorded for any of the Indian species of the genus. In analysing the species studied by Tanaka (1939) it is observed that $F$. complanata (Retz.) Link studied by him revealed $2 n=16$ where as the same species studied by us showed $n=5$ without ambiguity. Sharma (1962) also reported $n=5$ for this species. So Tanaka's report for this species is not free of doubt. Moreover in view of the large number of Indian species uniformly conforming to $\mathrm{x}=5$, the findings of $2 \mathrm{n}=24$ in $F$. makinoana and $2 \mathrm{n}=44$ in $F$. sericea $\mathrm{Br}$. of Tanaka also need confirmation. While $F$. makinoana is a Japanese species and we may not have the access for its study, $F$. sericea $\mathrm{Br}$. growing in Orissa needs checking during the future investigation.

While studying the morphology it was observed that there are certain species complexes within the genus Fimbristylis Vahl, Fimbristylis miliacea complex com- 
prises F. miliacea (L.) Vahl, F. complanata (Retz.) Link and F. quinquangularis (Vahl) Kunth, very slightly differing from each other in the shape of the spikelets and in the details of the structure of glume, style, stigma and nut. All the three species are also characterised by the haploid number of $n=5$. Hence the detail

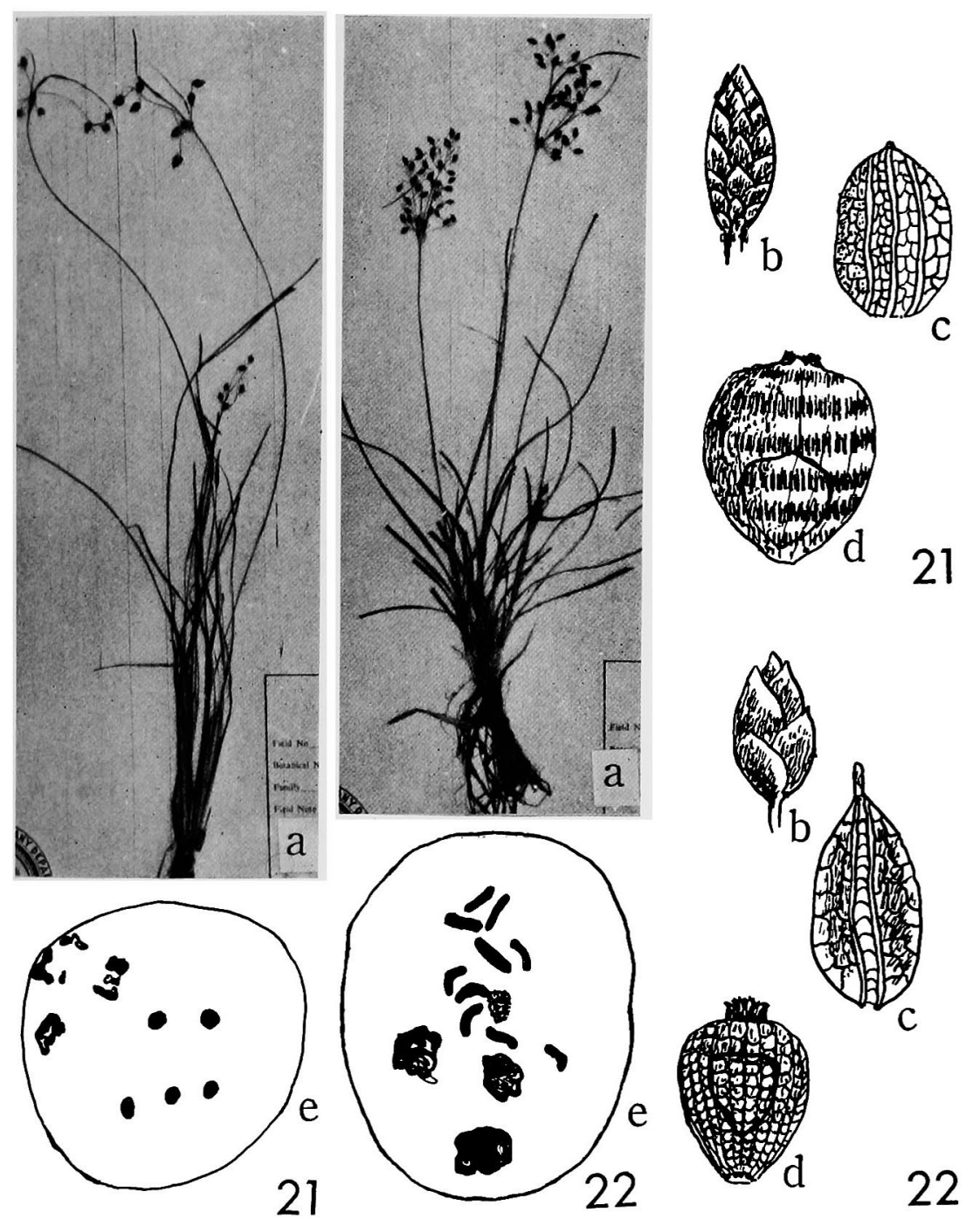

Figs. 21-22. 21, Fimbristylis diphylla (Retz.) Vahl. 21a, habit. 21b, spikelet. 21c, glume. 21d, nut. 21e, explanatory diagram of photomicrographed cell at a magnification of $\times 1,200$. 22 , Fimbristylis dichotoma (L.) Vahl. 22a, habit. 22b, spikelet. 22c, glume. 22d, nut. 22e, explanatory diagram of photomicrographed cell at a magnification of $\times 1,200$.

karyotypic analysis might help in differentiating these species. In this connection attention may be drawn to the work of Sharma and Bal (1956). While they observed "a general similarity in chromosome morphology between different species" of the genus Fimbristylis Vahl, they could reveal different pictures in the 
details of their karyotype.

Similarly, Fimbristylis diphylla (Retz.) Vahl, $F$. dichotoma (L.) Vahl and $F$. podocarpa Nees constitute another group of species complex. However, the cytological position in this group is slightly different from the previous group. One of the species within this complex is a tetraploid with $n=10$, but there is some amount of confusion regarding the identification of the species within this complex. This is quite evident when one consults the specimens of these species at Central National Herbarium at Sibpore, India. As $F$. diphylla (Retz.) Vahl recorded in 'Flora of British India' (Hooker 1894) is really $F$. dichotoma (L.) Vahl, majority of the specimens are corrected accordingly at $\mathrm{CNH}$. Similarly many specimens at $\mathrm{CNH}$ originally identified as $F$. dichotoma (L.) Vahl have been reidentified as $F$. diphylla (Retz.) Vahl. Some of the specimens of $F$. podocarpa Nees also have been assigned to $F$. dichotoma (L.) Vahl. $F$. dichotoma (L.) Vahl with its angled spikelets formed due to the keeled and dark coloured glumes differs from $F$. diphylla (Retz.) Vahl which is characterised by somewhat cylindrical spikelets formed by nonkeeled light brown glumes. Thus through the minor differences it becomes difficult to draw the lines of demarcation between these two species (Figs. 21-22). To add to this

Table 2. Different genera treated under Cyperus L. (sensu lato) with chromosome numbers discovered under each by different workers

Cyperus $\mathrm{L}$. (sensu stricto)
$\mathrm{n}=8,13,16,18,30,36,51,54$
Pycreus Beauv.
Cyperus $\mathrm{L}$.
$\mathrm{n}=21,24,25,40,47$.
(sensu lato)
Juncellus Kunth
$\mathrm{n}=29,43$

Kyllinga Rottb.
$\mathrm{n}=54,56,60$.

confusion our cytological finding is just the reverse of that of the previous workers. Sharma and Bal (1956) reported $2 \mathrm{n}=10$ for $F$. dichotoma (L.) Vahl and $2 \mathrm{n}=20$ for $F$. diphylla (Retz.) Vahl. Sharma (1962) also recorded $\mathrm{n}=5$ for $F$. dichotoma (L.) Vahl. Whereas our specimens identified recently in the light of corrections at $\mathrm{CNH}$ as $F$. dichotoma (L.) Vahl and $F$. diphylla (Retz.) Vahl revealed $\mathrm{n}=10$ and $\mathrm{n}=5$ respectively. This disagreement may be due to confusion in the identification of the two species. $F$. podocarpa Nees resembling very much the above two species, however, distinguishable to certain extent from them by the possession of a conspicuous gynophore.

The cytological position in Fimbristylis Vahl with large number of species conforming to a single basic chromosome number of $x=5$, therefore, seems to be different from that of the other genera like Eleocharis R. Br. Carex L. and Cyperus L. where very long series of aneuploid numbers are seen.

As contrast to the genus Fimbristylis Vahl the cytological analysis of only five species of the genus Cyperus L. could reveal wide array of haploid numbers such as $\mathrm{n}=8,13,18,21,29$. Here, however, the genus has been treated in its wider 
sense including the species of Pycreus Beauv. and Juncellus Kunth. Although very few species of each of the genera treated under Cyperus L. (sensu lato) have been studied, still the cytological picture is very significant in revealing a high state of aneuploid condition in this group (Table 2).

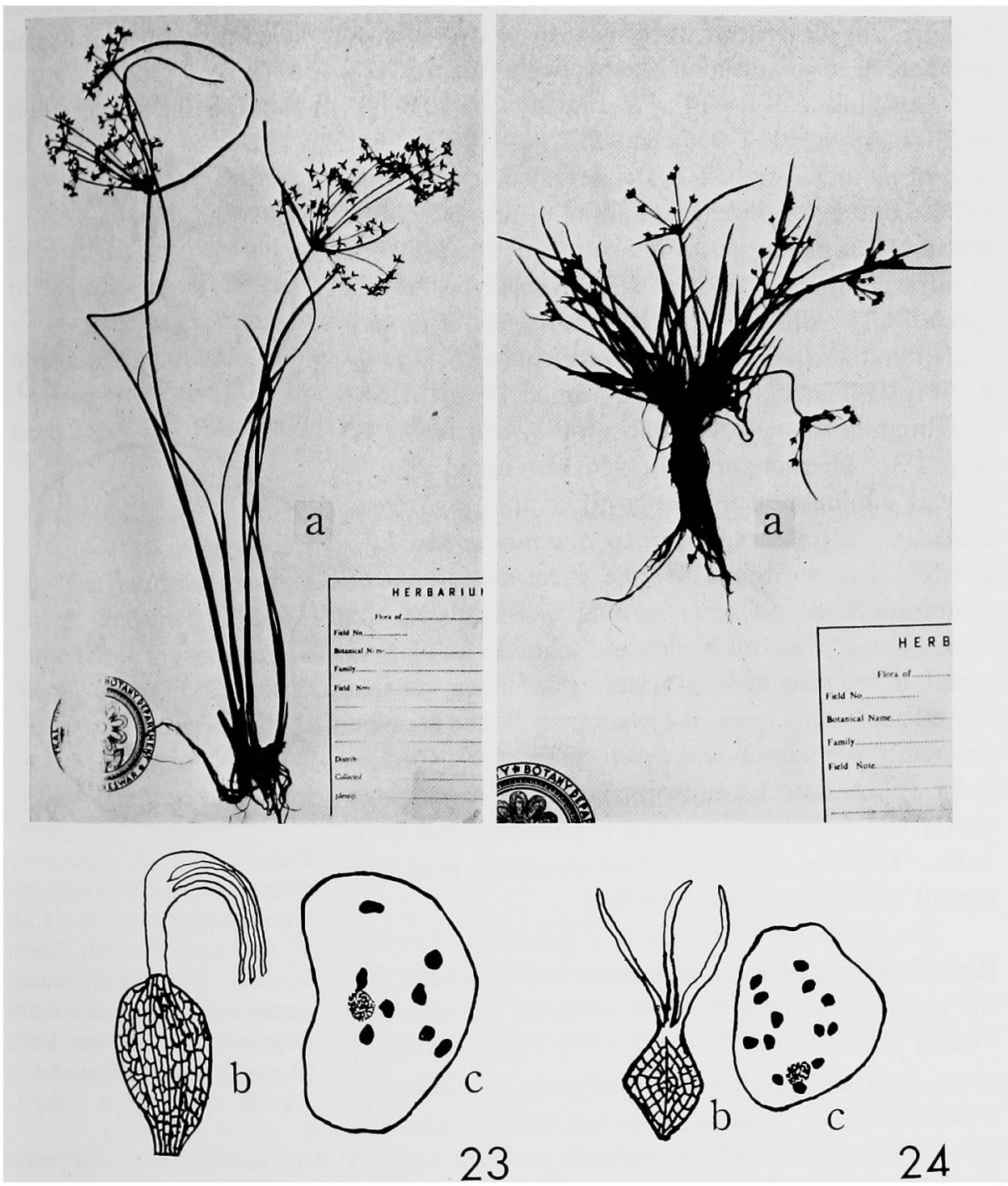

Figs. 23-24. 23, Cyperus tenuispica Steud. 23a, habit. 23b, nut. 23c, explanatory diagram of photomicrographed cell at a magnification of $\times 1,200$. 24, C. pulcherrimus Willd. 24a, habit. 24b, nut. $24 c$, explanatory diagram of photomicrographed cell at a magnification of $\times 1,200$.

While the cytological findings do not provide any clue for the merger of the genera like Pycreus Beauy., Juncellus Kunth and Kyllinga Rottb. with Cyperus L. (sense stricto), they certainly do not go against it. Here the determination of chromosome numbers seems to be very useful for delimitation of species because 
almost every species so far studied has been found to be characterised by a different chromosome number. In this connection comparison of two species Cyperus tenuispica Steud. and $C$. pulcherrimus Willd. is very significant. These two species are morphologically very closely allied to each other and Hooker (1894 p. 600) remarks that spikelets of $C$. pulcherrimus Willd. are very like those of $C$. tenuispica Steud. But the meiotic analysis in these two species revealed very different haploid numbers of $n=8$ and $n=13$ respectively (Figs. 23-24).

Our finding of $\mathrm{n}=14$ in Scirpus supinus L. (Fig. 14) confirms the earlier reports of Sharma and Bal (1956) and Sharma (1962). But $S$. articulatus $\mathrm{L}$. studied by us revealed $\mathrm{n}=15$ (Fig. 18 ) as contrast to the earlier finding of $2 n=32$ in this species. This may be an indication of the presence of intraspecific polyploidy in different biotypes of this species. The difference in chromosome size is very evident in these two species, the bivalents of S. supinus L. (Fig. 14) at diakinesis being much larger in size and brightly stained than those of $S$. articulatus $\mathrm{L}$. (Fig. 18). Sharma and Bal (1956) also noted that "a general diminuation in size is observable in Scirpus articulatus L. in comparison to Scirpus supinus L.". But this they attributed to "the effect arising out of the fixation in different fixatives". But using the same type of fixatives and uniform method of preparation, we observed conspicuous differences in size as well as staining reactions which may be the genuine nature of the chromosomes in these two species. Scirpus squarrosus L. studied, recently by Mohapatra (1971) was found to possess a haploid number of $n$ $=20$. Thus the same aneuploid condition seems to prevail also in the genus Scirpus L.

The discovery of $\mathbf{n}=13$ in Lipocarpha chinensis (Osbeck.) Kern establishes another basic number for the genus Lipocarpha $\mathrm{Br}$. as contrast to the previous finding of $x=23$ by Tanaka (1937). The finding of more than 100 bivalents at diakinesis in Eleocharis dulcis (Burm. f.) Trin. ex Henschel. supports the ear-

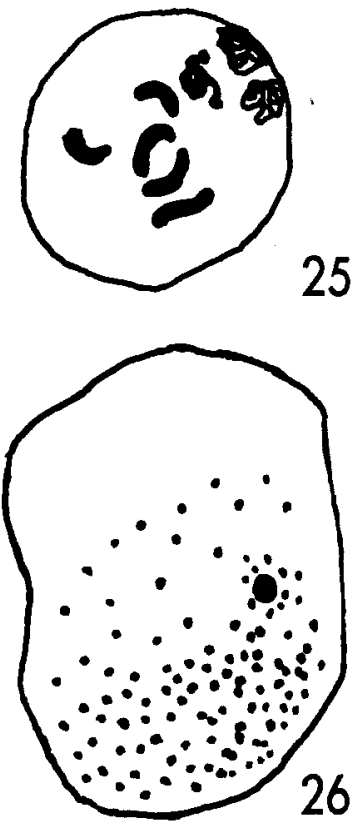

Figs. 25-26. 25, explanatory diagram of photomicrographed cell at a magnification of $\times 1,200$ of Eleocharis chaetaria Roem. et. Sch. $n=5$, pollen mitotic metaphase. 26, camera lucida diagram of Eleocharis dulcis (Burm.f.) Trin. ex Henschel. n $=\mathrm{c} .108$. lier finding of $n=c .108$ by Patnaik and Guru (1968) and justifies their statement that "such high chromosome number probably has not been recorded so far in the family Cyperaceae". This is again significant for the finding of $n=5$ in Eleocharis chaetaria Roem. et Sch. growing sympatrically with $E$. dulcis (Burm. f.) Trin. ex Henschel. (Figs. 25 and 26).

Thus the overall cytological picture in the family Cyperaceae reveals a great range of chromosome numbers ranging from the diploid number of 10 in Fimbristylis Vahl to more than 200 in Eleocharis $\mathrm{R}$. Br. It has also become evident that while euploidy and possibly gene mutations might be broadly responsible for the 
evolution of various species in the genus Fimbristylis Vahl aneuploidy had definitely played a great role in the speciation in the genera like Cyperus L., Carex L. and Eleocharis R. Br. and Scirpus L.

\section{Summary}

Cytology of 24 species belonging to five genera of the family Cyperaceae could be studied in which chromosome numbers are recorded for the first time in 15 species and different numbers have been discovered in 6 species against the previous reports.

All the 14 species of Fimbristylis Vahl cytologically investigated conformed to a single basic chromosome number of $x=5$. Of these, 12 species were proved to be diploids $(n=5)$ and 2 species were tetraploids $(n=10)$.

On the other hand the meiotic analysis of 5 species of Cyperus L. (sensu lato) revealed five different haploid numbers such as $\mathrm{n}=8,13,18,21$ and 29 .

An wide array of chromosome numbers were found in the family ranging from $2 \mathrm{n}=10$ in Fimbristylis Vahl to more than 200 in Eleocharis $\mathrm{R}$. Br.

\section{Acknowledgements}

The authors express their gratitude to Dr. B. Padhi, Professor of Botany, Utkal University, Vani Vihar, Bhubaneswar for facilities and encouragements throughout the progress of this work. Thanks are due to the Director, Botanical Survey of India, Calcutta for kindly permitting to consult the specimens at Central National Herbarium. Authors are also grateful to Dr. G. Panigrahi, Regional Botanist, Botanical Survey of India, Dr. V. N. Naik and Dr. V. D. Vartak for giving valuable suggestions regarding the identification and nomenclature of the specimens.

\section{Literature cited}

Clarke, C. B. 1909. Illustrations of Cyperaceae. Williams and Norget Publ. London.

Cooke, T. 1908. The Flora of the Presidency of Bombay. Vol. 2. Taylor and Francis. London. Darlington, C. D. and Wylie, A. P. 1955. Chromosome Atlas. Goerge Allen and Unwin Ltd. London.

Duthie, J. E. 1903-1923. Flora of upper Gangetic plain and of the adjacent Siwalik and sub Himalayan tracts. Bot. Surv. India Publ. Calcutta 2: 349-418.

Gamble J. S. and Fischer, C. E. C. 1936. Flora of Presidency of Madras Adlard \& Son and Newman, London.

Haines, H. H. 1924. The Botany of Bihar and Orissa. Adlard \& Son and West Newman. London. Heilborn, O. 1939. Chromosome studies in Cyperus, Eleocharis, Dulichium and Eriophorum. Bot. Gaz. 88: 132-49.

Hooker, J. D. 1894. The Flora of British India. Vol. 6. Reeve \& Co. Ltd. London.

Korlahalli, B. C. 1967. Notes on Indian Cyperaceae. Bull. Bot. Surv. India 9: 235-239.

Mohapatra, J. 1971. M.Sc. Thesis. (Unpublished)

Padhye, M. D. 1960. A contribution to the life history of Kyllinga triceps Rottb. Bot. Soc. Coll. Sci. Nagpur. Bull. 1: 1-15. 
- 1966-1967. The pollen grains of Kyllinga Rottb. Palynological Bull. 2 and 3: 101-103.

- 1971. Studies in Cyperaceae I. Embryology of Cyperus iria Linn. Indian Nat. Sci. Ass. Proc. 37: 1-10.

Padhye M. D. and Kasture, S. W. 1970. Studies in Cyperaceae V. Gametophytes and fertilization in Pycreus globossus All. var. niligiricus (Steud). C. B. Cl. Biol. Sci. 13 (2): 37-42.

Patnaik S. N. and Guru, K. M. 1968. A note on the cytotaxonomy of two species of Eleocharis R.Br. Samb. Univ. Journ. 1: 20-24.

Piech, K. 1928. Zytologische Studien an der Gattung Scirpus. Bull. Acad. Polon. Ser. 1/2: 1-43.

Prain, D. 1903. Bengal Plants. Calcutta.

Rath, S. P. and Patnaik, S. N. 1972. Cytotaxonomic studies in Cyperaceae. Proc. 59th Ind. Sc. Cong. Part III: 361.

Sabnis, S. D. 1962 . Cyperaceae of Gujrat. Bull. Bot. Surv. Ind. 6: 237-266.

Sharma, A. K. and Bal, A. K. 1956. A cytological investigation of some members of Cyperaceae $\phi$ yton 6 (1): 7-22.

Sharma, M. R. 1962. Cytology of Cyperaceae. Proc. Ind. Sci. Congr. Part III: 337.

Stebbins, G. L. 1950. Variation and Evolution in Plants. Columbia Univ. Press. New York.

Stewart, R. R. 1967. The Cyperaceae of Kasmir-A checklist. Bull. Bot. Surv. Ind. 9: 152-162.

Tanaka, N. 1937. Cytologia. F. J. N. 814.

- 1939a. Chromosome studies in Cyperaceae V. Pollen development of Carex grallatoria Maxim. var. heteroclita Kukenth. ex. Mutsum. Jap. Journ. Genet. 15: 153-57.

- 1939b. Chromosome studies in Cyperaceae VII. chromosome number and pollen develop. ment of Fimbristylis. Bot. Mag. Tokyo 53: 480-487.

- 1940. Chromosome studies in Cyperaceae VI. Pollen development and additional evidence for the compound chromosome in Scirpus lacustris L. Cytologia 10: 348-62.

Vartak, V. D. 1966. Importance of nut morphology in the classification of sedges. Proc. Autumn School in Botany. Mahabaleswar. 334-47.

Werner, D. 1967. Cytotaxonomy of Carex L. Section frigidae in Europe. Feddes Report Z. Bot. Taxon Geo. Bot. 75: 1-42. 